\title{
Antimicrobial peptides and pregnancy
}

\author{
Lorraine Frew and Sarah J Stock \\ MRC Centre for Reproductive Health, The Queens Medical Research Institute, University of Edinburgh, 47 Little \\ France Crescent, Edinburgh, EH16 4TJ, UK
}

Correspondence should be addressed to S J Stock; Email: sarah.stock@ed.ac.uk

\begin{abstract}
Antimicrobial peptides (AMPs) are small proteins produced by epithelial surfaces and inflammatory cells, which have broad-spectrum antimicrobial and immunomodulatory activities. They are known to be important in a number of infectious and inflammatory conditions and have been shown to be present in a number of sites throughout the female reproductive tract. Inflammation and infection are associated with a number of complications of pregnancy including preterm labor, and AMPs may play a key role in maintaining and protecting pregnancy. The aim of this review is to describe the expression and function of AMPs in the pregnant female reproductive tract and their relation to preterm labor.

Reproduction (2011) $\mathbf{1 4 1} 725-735$
\end{abstract}

\section{Introduction}

Antimicrobial peptides (AMPs) are genetically determined proteins that play a major part in both innate and adaptive immunity. They are an ancient form of host defense first established in lower phyla such as plants and invertebrates but now appreciated as being vital in the mammalian immune response. To date, more than 1600 AMPs have been identified or projected (http://aps. unmc.edu/AP/main.php; accessed 25 November 2010). A single species will express a variety of different proteins, either constitutively or after induction by inflammatory stimuli, which can act synergistically to provide broad-spectrum antimicrobial activity against bacteria, fungi, and some viruses (Hancock \& Rozek 2002). Although categorized by their antimicrobial activities, it has become clear that many mammalian AMPs are multifunctional molecules, with important roles in the modulation of inflammation and interaction with adaptive immunity (Ganz 2003).

In humans, deficiencies in AMPs have been implicated in pathogenesis of a number of infectious and inflammatory conditions. Deficiencies can result in loss of function of AMPs resulting in increased susceptibility to infection and inflammation, which play a role in many diseases (Beisswenger \& Bals 2005). They are likely to have important functions in the female reproductive tract, where infection and inflammation can jeopardize successful pregnancy. In this review, we will discuss the best-characterized human AMPs, defensins, cathelicidin, and the whey acidic protein motif containing proteins secretory leukocyte protease inhibitor (SLPI) and elafin/trappin-2, which have 'defensin-like' activities.
We outline their production and their relevance in the human female reproductive tract in pregnancy.

\section{AMP structure, expression, and regulation}

Table 1 summarizes the expression, regulation and functions of AMPs.

\section{Defensins}

Defensins are small cationic proteins containing 28-42 amino acids, which form triple-stranded $\beta$ sheets on a frame of six disulphide-linked cysteines. The classification into $\alpha$ - and $\beta$-defensins depends on the position of the cysteine bonds, but they have very similar tertiary structures (Zimmermann et al. 1995). A third class, the $\theta$-defensins, has been identified (Tang et al. 1999), that has a circular structure and enhanced antiviral activities (Lehrer 2004).

The $\alpha$-defensins (human neutrophil peptides 1-4; HNP1-4) are a product of neutrophils, forming $30-50 \%$ of the protein content of the azurophilic granules (Rice et al. 1987). They are also found in the Paneth cells of the small intestine (human defensins 5 and 6; HD5 and HD6; Selsted et al. 1992). In contrast, the human $\beta$-defensins (HBDs) are predominantly epithelial products. HBD1-4 are the best characterized, although many additional defensin genes have been identified (Scheetz et al. 2002, Schutte et al. 2002, Yamaguchi et al. 2002). HBD1-3 are widely expressed at epithelial surfaces, whereas HBD4 has more restricted expression, found in testis, stomach, uterus, neutrophils, 
Table 1 Summary of the expression, regulation and functions of AMPs.

\begin{tabular}{|c|c|c|c|c|}
\hline AMPs & Gene(s) & Regulation & Source & Main function \\
\hline SLPI & $S L P I$ & $\begin{array}{l}\text { Inducible expression by IL1B, } \\
\text { LPS, TNF, EGF, mycobacteria, } \\
\text { and viral dsRNA (POLY I:C) }\end{array}$ & $\begin{array}{l}\text { Epithelial cells: respiratory, } \\
\text { intestinal and genital tracts, } \\
\text { oral cavity } \\
\text { Neutrophils, macrophages, } \\
\text { and mast cells } \\
\text { Decidua }\end{array}$ & $\begin{array}{l}\text { Broad-spectrum antibacterial activity } \\
\text { against Gram }(+) \text { and Gram }(-) \\
\text { bacteria } \\
\text { Antiviral activity against HIV }\end{array}$ \\
\hline Elafin/trappin-2 & $P I 3$ & $\begin{array}{l}\text { Constitutive and inducible } \\
\text { expression by LPS, IL1B, } \\
\text { and TNF }\end{array}$ & $\begin{array}{l}\text { Epithelial cells: respiratory } \\
\text { and intestinal tract, skin } \\
\text { Neutrophils and macrophages } \\
\text { Decidua } \\
\text { Placental and chorion tropho- } \\
\text { blasts }\end{array}$ & $\begin{array}{l}\text { Broad-spectrum antibacterial activity } \\
\text { against Gram }(+) \text { and Gram }(-) \\
\text { bacteria } \\
\text { Induction of chemotactic agents, } \\
\text { neutrophils } \\
\text { Protease inhibition against human } \\
\text { neutrophil elastase and proteinase-3 }\end{array}$ \\
\hline LL37 & $C A M P$ & $\begin{array}{l}\text { Constitutive and inducible } \\
\text { expression by vitamin D } \\
\text { and LPS }\end{array}$ & $\begin{array}{l}\text { Epithelial cells: gut, urinary tract, } \\
\text { respiratory tract, skin }\end{array}$ & $\begin{array}{l}\text { Broad-spectrum antimicrobial activity } \\
\text { with specific activity against Group A } \\
\text { and B Streptococcus, Staphylococcus } \\
\text { aureus, Escherichia coli } \\
\text { Induction of chemotactic agents, } \\
\text { monocytes, neutrophils } \\
\text { Direct chemotactic activity } \\
\text { Angiogenesis }\end{array}$ \\
\hline \multicolumn{5}{|l|}{$\beta$-Defensins } \\
\hline HBD1 & $D E F B 1$ & Constitutive expression & $\begin{array}{l}\text { Epithelial cells: genitourinary } \\
\text { tract, lung, skin, gut }\end{array}$ & $\begin{array}{l}\text { Broad-spectrum antibacterial activity, } \\
\text { specifically active against Escherichia } \\
\text { coli, Pseudomonas aeruginosa }\end{array}$ \\
\hline HBD2 & $D E F B 4$ & $\begin{array}{l}\text { Inducible expression by IL1B, } \\
\text { Gram }(+) \text { and Gram }(-) \\
\text { bacteria, TNF, LPS and viral } \\
\text { dsRNA (POLY I:C) }\end{array}$ & Placental trophoblasts & Antiviral activity against HIV \\
\hline HBD3 & DEFB103 & $\begin{array}{l}\text { Inducible expression by Gram } \\
(+) \text { and Gram }(-) \text { bacteria, } \\
\text { TNF }\end{array}$ & Decidua & $\begin{array}{l}\text { Induction of cytokines IL8, IL6, } \\
\text { CCL2 (MCP-1), and IL10 }\end{array}$ \\
\hline \multicolumn{5}{|l|}{$\alpha$-Defensins } \\
\hline HNP1 & $D E F A 1,3$ & Constitutive expression & $\begin{array}{l}\text { Neutrophil azurophilic } \\
\text { granules }\end{array}$ & $\begin{array}{l}\text { Broad-spectrum antibacterial activity } \\
\text { against Gram }(+) \text { and } \operatorname{Gram}(-) \\
\text { bacteria }\end{array}$ \\
\hline HNP2 & $D E F A 1,3$ & Constitutive expression & & Antiviral activity \\
\hline HNP3 & $D E F A 1,3$ & Constitutive expression & & Angiogenesis \\
\hline HNP4 & DEFA 4 & Constitutive expression & & \\
\hline
\end{tabular}

thyroid, and kidney (Garcia et al. 2001b). HBD3 is also expressed in some non-epithelial tissues including skeletal and cardiac muscle and leukocytes (Garcia et al. 2001a).

Unlike the HNPs, which are stored, HBD concentrations are generally governed by synthesis and secretion rates. Production of HBD1 is generally constitutive, whereas HBD2 and HBD3 tend to be upregulated by a variety of inflammatory stimuli including bacteria, bacterial products, and inflammatory cytokines (Lai \& Gallo 2009). The $5^{\prime}$-flanking region of the $H B D 2$ gene contains NFKB, C/EBP, and AP- 1 binding sites (Tsutsumi-Ishii \& Nagaoka 2002), whereas the region of the $H B D 3$ gene has $\mathrm{C} / \mathrm{EBP}$ and $\mathrm{AP}-1$ sites (Jia et al. 2001), suggesting that these elements are important in HBD expression. In vivo, HBD2 and HBD3 tend to be found in epithelia in association with infection and inflammation, whereas HBD1 is often intrinsically present in healthy tissues (Lai \& Gallo 2009). HBDs can be downregulated by glucocorticoids and psychological stress, increasing susceptibility to infections (Aberg et al. 2007).

Most HBD genes are found in a cluster at $8 \mathrm{p} 23.1$ (Schutte et al. 2002), which is polymorphic in copy number (Hollox et al. 2005). Individuals have 2-12 copies of this repeat per diploid genome. The copy number is reflected in mRNA expression levels, and Crohn's disease has been associated with both a decreased copy number of DEFB4 and a decreased intestinal mRNA expression of HBD2 (Fellermann et al. 2006). A more recent study has failed to replicate these findings (Aldhous et al. 2010), and copy number polymorphisms are not associated with severity of lung disease in cystic fibrosis (Hollox et al. 2005). It remains to be observed whether the copy number correlates with other infectious or inflammatory conditions. 
Until recently, it was thought that humans had lost the capacity to produce $\theta$-defensin peptides, which are expressed in old world primates (Doss et al. 2009). Although humans express a gene with almost 90\% identity with the $\theta$-defensin gene from the rhesus macaque (Venkataraman et al. 2009), a premature stop codon in the upstream signaling sequence normally prevents translation (Klotman \& Chang 2006). Recently, Venkataraman et al. (2009) showed that human pro-myelocytic cells transfected with plasmids containing repaired retrocyclin-like genes had the ability to produce the cyclic antiviral peptides $\theta$-defensins. Aminoglycoside antibiotics also had the ability to readthrough the premature stop codon and produce functional peptides confirming that human cells do retain the ability to produce $\theta$-defensins (Venkataraman et al. 2009). This is of particular relevance in reproductive biology, as produced $\theta$-defensins have important anti-HIV activities (see below).

\section{Cathelicidin}

Like the defensins, cathelicidins are small basic peptides. In humans, only one cathelicidin gene has been identified, CAMP, which encodes a $18 \mathrm{kDa}$ precursor protein hCAP18. This is enzymatically processed to release the active form LL37, which has a $\boldsymbol{\alpha}$-helix structure (Lai \& Gallo 2009). Cathelicidin is expressed in neutrophils, macrophages, and epithelia (Sorensen 2005). In contrast to the defensins, expression is not directly influenced by inflammatory stimuli and found to be mediated through vitamin D (Bucki et al. 2010). The active form of vitamin D, 1,25 D3 increases transcription of hCAP18 directly, as well as upregulating inflammatory signaling components such as Toll-like receptors (TLRs) and CD14, thus further increasing other AMP expression and innate immune responses.

LL37, the active form of hCAP18, is released from the C-terminus by proteolytic enzymes such as proteinase 3 and kallikrein (Lai \& Gallo 2009). In human neutrophils, hCAP18 is usually processed to release LL37, whereas epithelial LL37 may be further processed into smaller peptides such as RK-31, KS-30, and K20 by bacterial proteases from microflora (Murakami et al. 2004). These derivatives exhibit significant heterogeneity in their antimicrobial activities.

\section{Secretory leukocyte protease inhibitor}

SLPI is a $11.7 \mathrm{kDa}$ protein consisting of 107 amino acids including 16 cysteine residues that form eight disulphide bridges (Seemuller et al. 1986). It is constitutively expressed by many epithelia, including the mucosa of the respiratory, intestinal and genital tracts, and oral cavity (Williams et al. 2006) as well as neutrophils, macrophages and mast cells (Bohm et al. 1992, Jin et al.
1997, Sallenave et al. 1997, Westin et al. 1999). The SLPI gene is localized on chromosome 20q12-13. 2 (Kikuchi et al. 1997) and is a non-polymorphic, stable gene but can be modulated at both the transcriptional and the translational levels (Maruyama et al. 1994). The promoter region has not been extensively studied, but early investigations demonstrated an AP-1 and AP-2 consensus site (Abe et al. 1991). Epithelial expression of SLPI appears to be tissue specific. It is increased by a variety of inflammatory stimuli including LPS, IL1B, TNF, EGF, HNPs, and human neutrophil elastase whereas antiinflammatory mediators such as TGFB and IL10 can decrease production (Williams et al. 2006).

\section{Elafin/trappin-2}

Elafin is a $9.9 \mathrm{kDa}$ protein composed of 95 amino acids and shows $40 \%$ sequence identity with the SLPI molecule (Sallenave \& Silva 1993). Encoded by the PI3 gene, expression is constitutive in a number of epithelial barriers constantly exposed to foreign antigens and pathogens, including skin, airway, and intestinal mucosa (Pfundt et al. 1996). PI3 is also expressed in neutrophils and macrophages and can be transcriptionally upregulated by LPS and pro-inflammatory cytokines such as IL1B and TNF (Sallenave et al. 1994, Pfundt et al. 2000, Simpson et al. 2001). PI3 has 5'-regulatory sites for NFKB and AP-1 (Zhang et al. 1995), and the response to cytokines appears to involve MAPK pathways in the skin (Pfundt et al. 2000) and NFKB pathways in the lung (Bingle et al. 2001). The PI3 gene is highly polymorphic, with 23 single-nucleotide polymorphisms (SNPs), 11 of which are in the promoter region (Chowdhury et al. 2006), and polymorphisms have recently been associated with low circulating elafin levels and increased risk of adult respiratory distress syndrome in critically ill patients (Tejera et al. 2009).

Elafin is released by proteolysis from a precursor protein, trappin-2, containing an N-terminal 'cementoin' domain that forms covalent bonds in extra-cellular matrix via tissue transglutaminases, anchoring the molecule to tissues (Nara et al. 1994). Its C-terminal domain contains an antiproteinase site that is similar to that of SLPI (Nara et al. 1994). There is some evidence that tissue bound trappin-2 is more effective at preventing elastase-mediated tissue damage in vivo (Tremblay et al. 2002).

\section{AMP functions}

Although recognized for their direct antimicrobial properties, it is increasingly clear that AMPs can help protect against infection by virtue of indirect immunomodulatory activities. Indeed, in some instances, other AMP functions, such as chemokine and antiendotoxin activities, may be more important than their direct 
antimicrobial functions in the resolution of infection. The functions of AMPs are illustrated in Fig. 1.

\section{Antimicrobial effects}

In vitro, AMPs have broad-spectrum antimicrobial activity against bacteria, viruses (including HIV), and fungi (reviewed by Reddy et al. (2004)). These effects appear to be synergistic with each other and other classes of AMPs (Chen et al. 2005). AMPs may have enhanced antimicrobial efficiency at low $\mathrm{pH}$ (4.6) (Valore et al. 1998) and in vitro activity is salt dependent (Jenssen et al. 2006).

It has been postulated that microbial killing by AMPs may be effected via a variety of mechanisms including membrane depolarization, membrane permeablization, induction of hydrolases, disruption of membrane functions, and/or damage of critical intracellular proteins (Zasloff 2002, Lai \& Gallo 2009). Crucial to all these processes are selective interactions with the membranes of microorganisms. Increasing ionic strength generally decreases antimicrobial activity, probably via reducing the strength of initial interactions. Mammalian cell membranes are mainly constructed by zwitterionic phospholipids, which have no net charge overall, and any phospholipids with anionic head groups tend to face inward. They are also stabilized by high cholesterol content. In contrast, prokaryote membranes have many highly anionic phospholipids orientated outward which interact with positively charged, hydrophobic antimicrobials. AMPs may form aggregates in the lipid bilayer, physically disrupting it, and, in some cases, allowing

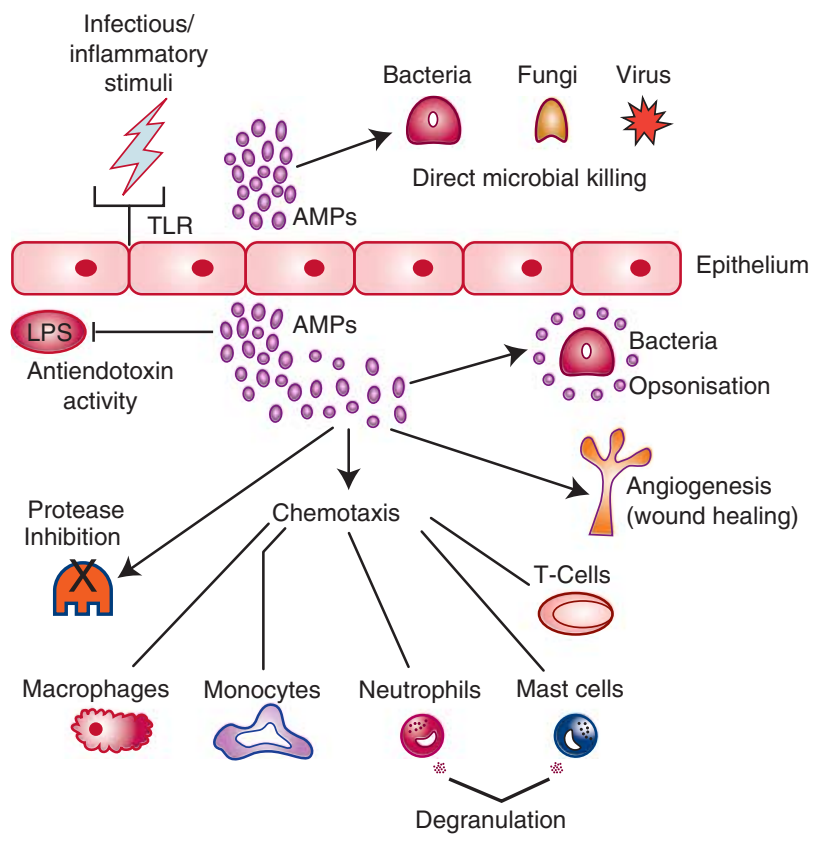

Figure 1 Summary illustrating the function of epithelial AMPs. diffusion of peptides to intracellular targets (Matsuzaki 1999, Shai 1999, Yang et al. 2000).

In vivo models have shown increased susceptibility to infection with AMP knockdown (Gallo \& Nizet 2008) or improved resolution of infection with forced expression (Simpson et al. 2001). However, the minimal inhibitory concentrations required for bactericidal activity in vitro are often considerably higher than normal physiological AMP concentrations (Lai \& Gallo 2009). Various explanations have been suggested to explain this apparent contradiction, including that AMPs act synergistically, or that high concentrations of AMPs accumulate locally in association with inflammation. However, AMPs also have indirect effects that may help to eradicate infection.

\section{Immunomodulation}

AMPs can act as opsonins to aid clearance of bacteria by inflammatory cells (Wilkinson et al. 2009). AMPs have also been variously shown to be chemotactic for monocytes, macrophages, neutrophils, mast cells, dendritic cells, and T-cells (Oppenheim et al. 2003). They can indirectly recruit leukocytes through upregulation of inflammatory cytokines and other chemokines including IL8, IL6, and CCL2 (MCP-1) (Lai \& Gallo 2009).

AMPs also exhibit antiinflammatory or pro-resolution functions, being capable of inducing production of antiinflammatory cytokines such as IL10 and TGFB (Lai \& Gallo 2009). They can interact with pattern recognition receptors such as TLRs. These are expressed in cells involved in the first line of host defense including neutrophils, macrophages, and mucosal epithelial cells (Fazeli et al. 2005). There are ten TLRs in humans with each one having specificity for different pathogen products, which work collectively to alert the immune system to detection of a pathogen (Fazeli et al. 2005). TLRs generate intra-cellular signals through NFKBdependent and independent pathways to mediate inflammation and elimination of pathogens. Cathelicidin has been shown to inhibit TLR-mediated induction of cytokine release and maturation of dendritic cells (Di Nardo et al. 2007). AMPs can also modulate components of TLR signaling pathways such as NFKB (Lai \& Gallo 2009) and bind and neutralize LPS, a TLR ligand, thus indirectly altering TLR responses (McMichael et al. 2005, Rosenfeld et al. 2006).

\section{Protease inhibition}

Although the innate immune response to pathogens is designed to protect the host, the inflammatory response mediated through this system can potentially result in considerable damage to the host tissue. This is in part mediated by proteases that are produced by a number of phagocytic inflammatory cells to degrade ingested 
pathogens (Dallegri \& Ottonello 1997, Williams et al. 2006). The host responds to this by secreting antiprotease molecules in order to protect the host tissue and neutralize any excess protease (Williams et al. 2006). SLPI and elafin/trappin-2 have antiprotease activity (Sallenave 2010). SLPI can inhibit a variety of human neutrophil proteases including cathepsin G, trypsin, chymotrypsin, and chymase; however, its greatest activity seems to be against neutrophil elastase (Thompson \& Ohlsson 1986, Boudier \& Bieth 1992). Trappin-2 has more restricted antiprotease activity to SLPI, inhibiting porcine pancreatic elastase, human neutrophil elastase, and proteinase-3 (Schalkwijk et al. 1999).

\section{Tissue remodeling}

Wound healing and tissue remodeling are other processes involving AMPs. AMPs are produced in response to cutaneous injury (vanBergen et al. 1996, Wingens et al. 1998), and AMP knockout mice show impaired cutaneous wound healing and increased inflammation and elastase activity (Ashcroft et al. 2000, Angelov et al. 2004). AMPs present at the site of wound repair may also be protecting the wound from potential infection, with HBD1-3 shown to be present in human wound fluid (Frohm et al. 1996).

\section{AMPs in pregnancy}

The female reproductive tract is split into upper (endocervix and uterus) and lower (ectocervix and vagina) compartments, which are distinct in their morphology, microenvironment, and function (Kaushic 2011). The lower compartment of the genital tract is continuously exposed to the external environment and must be able to distinguish between commensal microflora and pathogens (Kaushic 2011). In the non-pregnant female genital tract, expression of AMPs varies with site, which may promote tolerance to certain bacteria in the vagina, but effect elimination of pathogens in the uterine cavity (Soboll et al. 2006). Production has been shown to be influenced by steroid hormones, and expression varies with the menstrual cycle (King et al. 2003a, 2003b), suggesting a protective effect at key times such as menstruation and implantation. The production of AMPs may be involved in the prevention of a variety of reproductive complications including subfertility and ectopic pregnancy (Horne et al. 2008). Studies using PCR of bacterial DNA have shown that in pregnancy, the upper genital tract is also usually sterile prior to the onset of labor (Jones et al. 2009). Infection resulting from the ascension of vaginal bacteria to the uterus is associated with pregnancy complications including preterm labor, neonatal infection, and post partum endometritis. Viral infections, such as HIV, herpes simplex and human papilloma virus may jeopardize the health of mother and babies. The expression and regulation of AMPs in pregnancy suggest that they may have a role in preventing such complications, and there is increasing evidence that deficient or defective production is associated with disease.

\section{Expression of AMPs}

The expression of natural antimicrobial RNA and protein by maternal and fetal tissues in pregnancy are summarized in Figs 2 and 3.

HBD1-3 are widely expressed in the pregnant uterus, with expression detected in the amnion, deciduas, chorion, and placental trophoblasts (Feng et al. 2003, Buhimschi et al. 2004, King et al. 2007a, 2007b, Stock et al. 2007). HBD1 and HBD2 mRNA expression has also been located in the chorion, placenta, and umbilical cord (Feng et al. 2003). HBD1-3 peptides have also been identified in amniotic fluid obtained

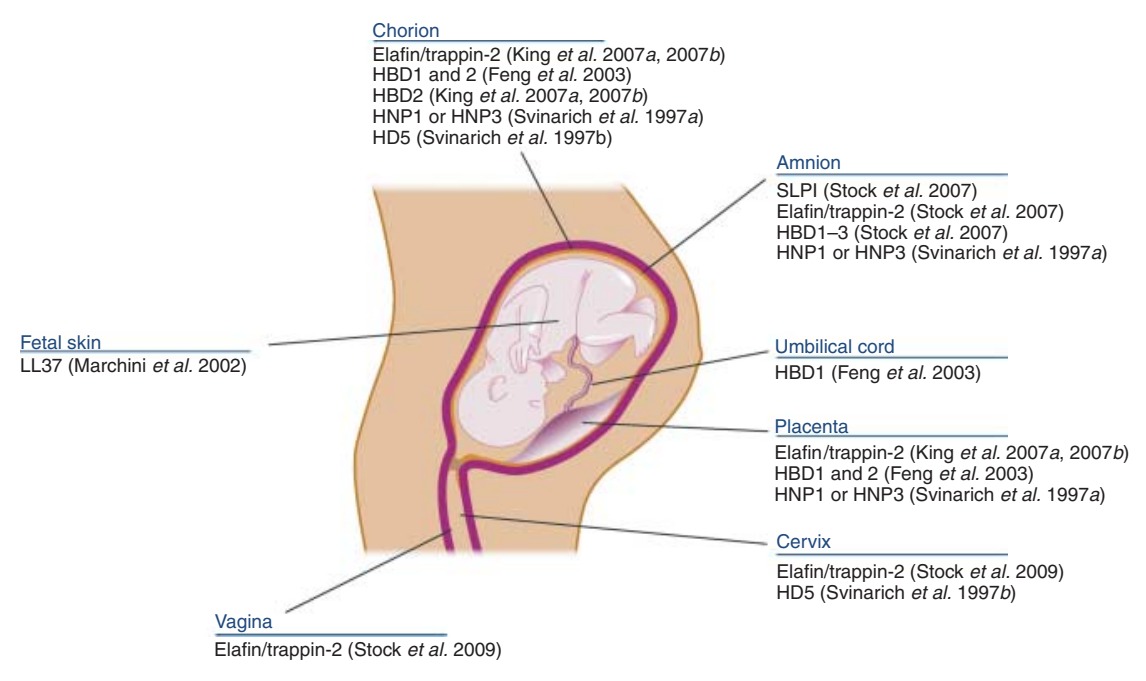

Figure 2 Expression of AMP RNA by maternal and fetal tissue in pregnancy. 


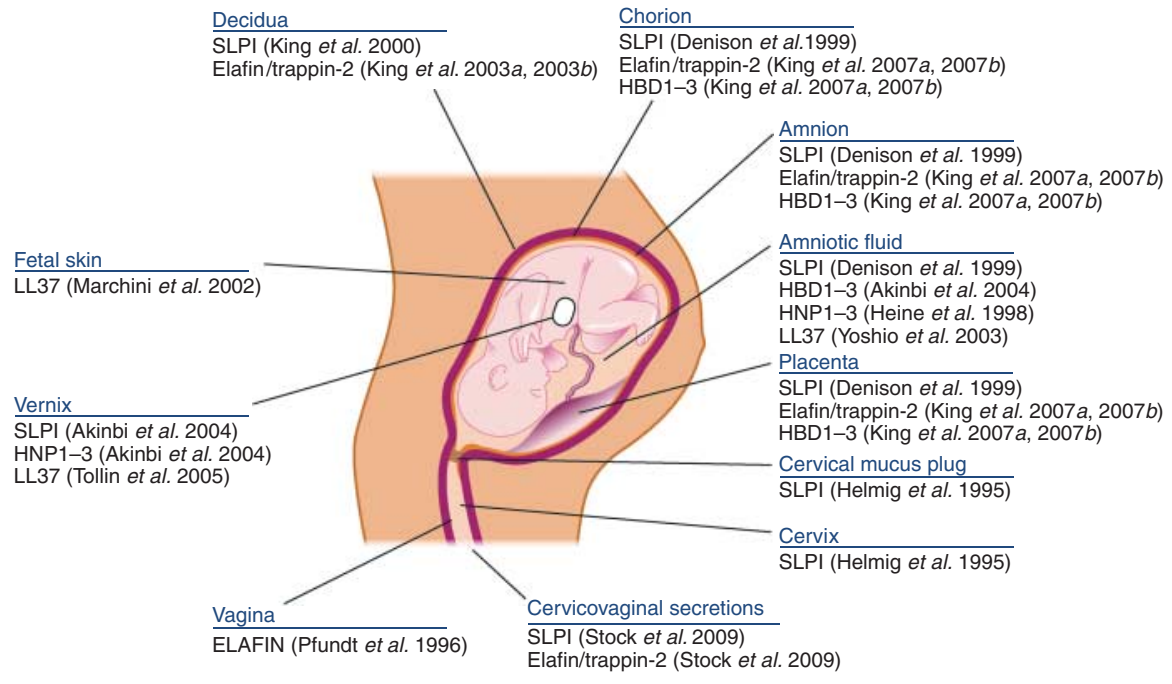

Figure 3 Expression of AMP protein by maternal and fetal tissue in pregnancy. from term pregnancy (Akinbi et al. 2004). Detection of mRNA corresponding to HNP1 or HNP3 had been found in amnion, chorion, and placental tissue (Svinarich et al. 1997a), and HD5 mRNA was also found in samples from the chorion and cervix (Svinarich et al. 1997b). The expression of HNP1-3 has been identified in amniotic fluid, with levels significantly higher in patients presenting with an intrauterine infection (Heine et al. 1998). The expression of HNP1-3 has also been shown in the vernix caseosa, the substance covering and protecting the skin of the fetus (Akinbi et al. 2004).

Cathelicidin LL37 has also been identified in high concentration within the vernix caseosa (Tollin et al. 2005) as well as on fetal skin, in much higher concentration than found in healthy adults (Marchini et al. 2002). Protein expression of LL37 has also been identified in amniotic fluid (Yoshio et al. 2003) and in non-pregnant vaginal fluid (Valore et al. 2002).

SLPI has been localized in first trimester deciduas (King et al. 2000) and in the amnion epithelium and deciduas at term (Denison et al. 1999, Zhang et al. 2001). SLPI is also found in amniotic fluid, with levels shown to rise between the second and the third trimester and continuing to increase at the time of term labor (Denison et al. 1999, Zhang et al. 2001). High concentrations of SLPI have been identified in the vernix caseosa (Akinbi et al. 2004) and in the cervical mucus plug and cervical tissue (Helmig et al. 1995, Hein et al. 2002). Protein expression of both SLPI and elafin/ trappin-2 has also been identified in cervicovaginal secretions from the pregnant tract (Stock et al. 2009). Elafin/trappin-2 is found at low levels in first trimester deciduas (King et al. 2003a). Protein expression has been identified in both the fetal membranes and the placenta at term, identified strongly in the amnion epithelium, deciduas, chorion trophoblasts, and placenta syncytiotrophoblasts (Hein et al. 2002, King et al. 2007a, 2007 b).
Expression at mRNA of elafin/trappin-2 has been also been shown in both vaginal and cervical cells (Stock et al. 2009).

\section{AMPs and preterm labor}

Preterm birth is the leading cause of neonatal morbidity and mortality and results in a substantial burden of longterm complications (Beck et al. 2010). All parturition is associated with inflammation of the intrauterine tissues, and in preterm labor inflammatory response is particularly vigorous (Romero et al. 2006). A causal link between infection and prematurity has been established, with at least $40 \%$ of all preterm births associated with infection and lower gestational age being linked to a higher frequency of intrauterine infection (Romero et al. 2003). The majority of infections found in the uterine cavity associated with preterm labor are of vaginal origin (Epstein et al. 2000, Jones et al. 2009); however, antibiotics have been disappointing in preventing preterm birth (Simcox et al. 2007). Alterations in AMP levels have been associated with infections that may lead to preterm birth as well as preterm labor and rupture of membranes. They make attractive therapeutic targets for the prediction and prevention of infection associated with preterm labor (Horne et al. 2008).

The $\alpha$-defensins have been associated with increased risk of premature delivery; women showing elevated levels of neutrophil defensins in vaginal fluid had a greater risk of premature delivery before 32 weeks compared with women with no levels of defensins present (Balu et al. 2003). A SNP has also been identified within the maternal $\alpha$-defensin HD5 gene that has been identified as part of a locus that is associated with preterm premature rupture of the membranes (Romero et al. 2010). The presence of bacterial vaginosis in the reproductive tract has been shown to reduce the 
concentration of AMPs compared with cervicovaginal fluid from healthy women; however, when effective treatment of the bacterial vaginosis is administered, the levels of antimicrobials are normalized suggesting that reduction is due to the presence of the disease (Valore et al. 2006).

Epithelially produced defensins have also been found to be altered in association with preterm labor. HBD2 expression in the placenta and the fetal membranes is upregulated by inflammatory cytokines (King et al. 2007b, Stock et al. 2007), and HBD2 concentrations are elevated in amniotic fluid from patients with preterm delivery due to microbial invasion of the amniotic cavity (Soto et al. 2007). Mid-trimester amniotic fluid concentrations of HBD2, but not HBD3, have also been associated with preterm premature rupture of membranes (Xu et al. 2008). However, HBD3 protein expression is increased in fetal membranes of patients with preterm delivery associated with chorioamnionitis (Buhimschi et al. 2004).

Cervicovaginal levels of elafin/trappin-2 in pregnancy have been associated with bacterial vaginosis, itself associated with preterm labor (Stock et al. 2009). Trappin-2 mRNA and protein expression in fetal membranes of pregnancies complicated with chorioamnionitis have an increase, suggesting upregulation of trappin-2 in response to infection (Tromp et al. 2004). In addition, the concentration of SLPI in amniotic fluid (Helmig et al. 2002) and mRNA of protein expression of trappin-2 is reduced in cases of prelabor rupture of membranes compared with women with intact membranes (Tromp et al. 2004).

\section{AMPs and neonatal infection}

Neonatal sepsis is particularly associated with preterm delivery (Gonzalez et al. 2003); however, intrauterine infection and inflammation increase neonatal morbidity even when gestation is adjusted. Constitutive expression of AMPs is developmentally controlled and influenced by gestation (Starner et al. 2005). The developing fetus expresses AMPs in skin, lung, gut, and vernix, and it has been hypothesized that they may have a specialized role in protecting the developing fetus and neonate from infection. Pulmonary infections in preterm neonates are associated with significantly increased concentrations of LL37, HBD1, and HBD2 in tracheal aspirates (Schaller-Bals et al. 2002). There is some evidence that cathelicidin is transferred transplacentally from mother to fetus (Mandic Havelka et al. 2010). Levels are higher in cord blood after normal delivery compared with caesarean section indicating release at this vulnerable time. The presence of fetally derived HNP1 and HNP2 in amniotic fluid is associated with a fetal inflammatory response (Buhimschi et al. 2005).

\section{AMPs and HIV infection}

Several AMPs present in the reproductive tract are emerging as effective inhibitors of HIV-1 infection in vitro, and recent evidence implicates $\alpha$-defensins in resistance of HIV-1 progression in vivo (Cole \& Lehrer 2003). Cervicovaginal secretions measured from healthy HIV-positive and HIV-negative women contained the antimicrobials HBD2, elafin/trappin-2, and SLPI, with HBD2 correlated with anti-HIV activity in the HIVpositive patients (Ghosh et al. 2010a). Elafin/trappin-2 has also been shown to have an inhibitory activity against HIV-1 in vitro when incubated with epithelial cells of the female reproductive tract directly with the virus, but not if the AMP was added before or after infection with the virus, suggesting a direct mechanism of inhibition between elafin/trappin-2 and HIV-1 (Ghosh et al. 2010b).

\section{AMPs as therapeutic agents}

The broad range of antimicrobial, antiviral, and immunomodulatory effects that AMPs possess make them potential novel therapeutic agents for the treatment of infectious and inflammatory diseases. AMPs are under development as a treatment in the lung and skin, and could be developed as topical antiinflammatory and antimicrobial agents in the lower genital tract. This could be an important alternative strategy to the prevention of infection and inflammatory complications.

AMP-based treatments offer several advantages over currently used classes of drugs (Jenssen et al. 2006). One of the main advantages that AMP treatment may have is the substantially reduced risk of resistance that is currently associated with antibiotics. AMPs have several targets on microbial cells allowing them to be less specific than some antibiotics that allow for a lower risk for the emergence of resistance. AMP therapy could be applied in combination with antibiotics to give an additive effect and relieve the pressure of a single molecular target. Synthetic AMPs can be modified to enhance antimicrobial activity further. Additionally, the ability of AMPs such as elafin/trappin-2 to bind to tissues via transglutaminase-catalyzed covalent bonds increases its potential to be retained in the cervix.

\section{Summary}

AMPs are expressed at a number of sites throughout the pregnant female reproductive tract where they have the capacity to carry out a number of functions that may play key roles in maintaining and protecting the fetus during pregnancy. AMPs have many responses to infectious and inflammatory stimuli with elevated expression observed at a number of sites in response to intrauterine infection, a factor associated with an increased risk of preterm delivery. Further understanding of the function of AMPs 
and their mechanisms of actions will allow them to be considered in new strategies as therapeutic agents in controlling human diseases including pregnancy complications such as preterm labor.

\section{Declaration of interest}

The authors declare that there is no conflict of interest that could be perceived as prejudicing the impartiality of the research reported.

\section{Funding}

Funding was provided by a Clinical Lecturer Starter Grant from the Academy of Medical Sciences and Wellcome Trust and Tommy's (www.tommys.org).

\section{Acknowledgements}

The authors would like to thank Ronnie Grant (CRB Visual Aids, University of Edinburgh) for graphic design.

\section{References}

Abe T, Kobayashi N, Yoshimura K, Trapnell BC, Kim H, Hubbard RC, Brewer MT, Thompson RC \& Crystal RG 1991 Expression of the secretory leukoprotease inhibitor gene in epithelial-cells. Journal of Clinical Investigation 87 2207-2215. (doi:10.1172/JCI115255)

Aberg KM, Radek KA, Choi E-H, Kim D-K, Demerjian M, Hupe M, Kerbleski J, Gallo RL, Ganz T, Mauro T et al. 2007 Psychological stress downregulates epidermal antimicrobial peptide expression and increases severity of cutaneous infections in mice. Journal of Clinical Investigation 117 3339-3349. (doi:10.1172/JCI31726)

Akinbi HT, Narendran V, Pass AK, Markart P \& Hoath SB 2004 Host defense proteins in vernix caseosa and amniotic fluid. American Journal of Obstetrics and Gynecology 191 2090-2096. (doi:10.1016/j.ajog.2004. 05.002)

Aldhous MC, Abu Bakar S, Prescott NJ, Palla R, Soo K, Mansfield JC, Mathew CG, Satsangi J \& Armour JAL 2010 Measurement methods and accuracy in copy number variation: failure to replicate associations of beta-defensin copy number with Crohn's disease. Human Molecular Genetics 19 4930-4938. (doi:10.1093/hmg/ddq411)

Angelov N, Moutsopoulos N, Jeong MJ, Nares S, Ashcroft G \& Wahl SM 2004 Aberrant mucosal wound repair in the absence of secretory leukocyte protease inhibitor. Thrombosis and Haemostasis 92 288-297. (doi:10.1160/TH03-07-0446)

Ashcroft GS, Lei KJ, Jin WW, Longenecker G, Kulkarni AB, GreenwellWild T, Hale-Donze H, McGrady G, Song XY \& Wahl SM 2000 Secretory leukocyte protease inhibitor mediates non-redundant functions necessary for normal wound healing. Nature Medicine 6 1147-1153. (doi:10. 1038/80489)

Balu RB, Savitz DA, Ananth CV, Hartmann KE, Miller WC, Thorp JM \& Heine RP 2003 Bacterial vaginosis, vaginal fluid neutrophil defensins, and preterm birth. Obstetrics and Gynecology 101 862-868. (doi:10. 1016/S0029-7844(03)00042-5)

Beck S, Wojdyla D, Say L, Betran AP, Merialdi M, Requejo JH, Rubens C, Menon R \& Van Look PFA 2010 The worldwide incidence of preterm birth: a systematic review of maternal mortality and morbidity. Bulletin of the World Health Organization 88 31-38. (doi:10.2471/BLT.08.062554)

Beisswenger C \& Bals R 2005 Antimicrobial peptides in lung inflammation. Chemical Immunology Allergy 86 57-71. (doi:10.1159/000086651)

vanBergen BH, Andriessen MPM, Spruijt KIJ, vandeKerkhof PCM \& Schalkwijk J 1996 Expression of SKALP/elafin during wound healing in human skin. Archives of Dermatological Research 288 458-462. (doi:10. 1007/BF02505235)
Bingle L, Tetley TD \& Bingle CD 2001 Cytokine-mediated induction of the human elafin gene in pulmonary epithelial cells is regulated by nuclear factor-kappa B. American Journal of Respiratory Cell and Molecular Biology 25 84-91.

Bohm B, Aigner T, Kinne R \& Burkhardt H 1992 The serine-protease inhibitor of cartilage matrix is not a chondrocytic gene-product. European Journal of Biochemistry 207 773-779. (doi:10.1111/j.14321033.1992.tb17108.x)

Boudier C \& Bieth JG 1992 The proteinase - mucus proteinaseinhibitor binding stoichiometry. Journal of Biological Chemistry 267 4370-4375.

Bucki R, Leszczynska K, Namiot A \& Sokolowski W 2010 Cathelicidin LL-37: a multitask antimicrobial peptide. Archivum Immunologiae et Therapiae Experimentalis 58 15-25. (doi:10.1007/s00005-009-0057-2)

Buhimschi IA, Jabr M, Buhimschi CS, Petkova AP, Weiner CP \& Saed GM 2004 The novel antimicrobal peptide beta 3-defensin is produced by the amnion: a possible role of the fetal membranes in innate immunity of the amniotic cavity. American Journal of Obstetrics and Gynecology 191 1678-1687. (doi:10.1016/j.ajog.2004.03.081)

Buhimschi IA, Christner R \& Buhimschi CS 2005 Proteomic biomarker analysis of amniotic fluid for identification of intra-amniotic inflammation. BJOG : an International Journal of Obstetrics and Gynaecology 112 173-181. (doi:10.1111/j.1471-0528.2004.00340.x)

Chen XJ, Niyonsaba F, Ushio H, Okuda D, Nagaoka I, Ikeda S, Okumura K \& Ogawa H 2005 Synergistic effect of antibacterial agents human beta-defensins, cathelicidin LL-37 and lysozyme against Staphylococcus aureus and Escherichia coli. Journal of Dermatological Science $\mathbf{4 0}$ 123-132. (doi:10.1016/j.jdermsci.2005.03.014)

Chowdhury MA, Kuivaniemi H, Romero R, Edwin S, Chaiworapongsa T \& Tromp G 2006 Identification of novel functional sequence variants in the gene for peptidase inhibitor 3. BMC Medical Genetics 7 49. (doi:10. 1186/1471-2350-7-49)

Cole AM \& Lehrer RI 2003 Minidefensins: antimicrobial peptides with activity against HIV-1. Current Pharmaceutical Design 9 1463-1473. (doi:10.2174/1381612033454667)

Dallegri F \& Ottonello L 1997 Tissue injury in neutrophilic inflammation. Inflammation Research 46 382-391. (doi:10.1007/s000110050208)

Denison FC, Kelly RW, Calder AA \& Riley SC 1999 Secretory leukocyte protease inhibitor concentration increases in amniotic fluid with the onset of labour in women: characterization of sites of release within the uterus. Journal of Endocrinology 161 299-306. (doi:10.1677/joe.0. 1610299)

Di Nardo A, Braff MH, Taylor KR, Na CR, Granstein RD, McInturff JE, Krutzik S, Modlin RL \& Gallo RL 2007 Cathelicidin antimicrobial peptides block dendritic cell TLR4 activation and allergic contact sensitization. Journal of Immunology 178 1829-1834.

Doss M, White MR, Tecle T \& Hartshorn KL 2009 Human defensins and LL-37 in mucosal immunity. Journal of Leukocyte Biology 87 79-92. (doi:10.1189/jlb.0609382)

Epstein FH, Goldenberg RL, Hauth JC \& Andrews WW 2000 Intrauterine infection and preterm delivery. New England Journal of Medicine 342 1500-1507. (doi:10.1056/NEJM200005183422007)

Fazeli A, Bruce C \& Anumba DO 2005 Characterization of Toll-like receptors in the female reproductive tract in humans. Human Reproduction 20 1372-1378. (doi:10.1093/humrep/deh775)

Fellermann K, Stange DE, Schaeffeler E, Schmalzl H, Wehkamp J, Bevins CL, Reinisch W, Teml A, Schwab M, Lichter P et al. 2006 A chromosome 8 gene-cluster polymorphism with low human betadefensin 2 gene copy number predisposes to Crohn disease of the colon. American Journal of Human Genetics 79 439-448. (doi:10.1086/ 505915)

Feng Y, Pan X, Huang N, Feng Y, Wu Q \& Wang B 2003 The human betadefensins expression in female genital tract and pregnancy-related tissues. Sichuan Da Xue Xue Bao Yi Xue Ban 34 217-219.

Frohm M, Gunne H, Bergman AC, Agerberth B, Bergman T, Boman A, Liden S, Jornvall H \& Boman HG 1996 Biochemical and antibacterial analysis of human wound and blister fluid. European Journal of Biochemistry 237 86-92. (doi:10.1111/j.1432-1033.1996.0086n.x)

Gallo RL \& Nizet V 2008 Innate barriers against skin infection and associated disorders. Drug Discovery Today: Disease Mechanisms 5 e145-e152. (doi:10.1016/j.ddmec.2008.04.009) 
Ganz T 2003 The role of antimicrobial peptides in innate immunity. Integrative and Comparative Biology 43 300-304. (doi:10.1093/icb/43. 2.300)

Garcia JRC, Jaumann F, Schulz S, Krause A, Rodriguez-Jimenez J, Forssmann U, Adermann K, Kluver E, Vogelmeier C, Becker D et al. 2001 a Identification of a novel, multifunctional beta-defensin (human beta-defensin 3) with specific antimicrobial activity - its interaction with plasma membranes of Xenopus oocytes and the induction of macrophage chemoattraction. Cell and Tissue Research 306 257-264. (doi:10 1007/s004410100433)

Garcia JRC, Krause A, Schulz S, Rodriguez-Jimenez FJ, Kluver E, Adermann K, Forssmann U, Frimpong-Boateng A, Bals $\mathbf{R} \&$ Forssmann WG 2001b Human beta-defensin 4: a novel inducible peptide with a specific salt-sensitive spectrum of antimicrobial activity. FASEB Journal 15 1819-1821.

Ghosh M, Fahey JV, Shen Z, Lahey T, Cu-Uvin S, Wu Z, Mayer K, Wright PF, Kappes JC, Ochsenbauer C et al. 2010a Anti-HIV activity in cervicalvaginal secretions from HIV-positive and -negative women correlate with innate antimicrobial levels and IgG antibodies. PLOS ONE 5 e11366. (doi:10.1371/journal.pone.0011366)

Ghosh M, Shen Z, Fahey JV, Cu-Uvin S, Mayer K \& Wira CR $2010 b$ Trappin2/elafin: a novel innate anti-human immunodeficiency virus-1 molecule of the human female reproductive tract. Immunology 129 207-219. (doi:10.1111/j.1365-2567.2009.03165.x)

Gonzalez BE, Mercado CK, Johnson L, Brodsky NL \& Bhandari V 2003 Early markers of late-onset sepsis in premature neonates: clinical, hematological and cytokine profile. Journal of Perinatal Medicine 31 60-68. (doi:10.1515/JPM.2003.009)

Hancock RE \& Rozek A 2002 Role of membranes in the activities of antimicrobial cationic peptides. FEMS Microbiology Letters 206 143-149. (doi:10.1111/j.1574-6968.2002.tb11000.x)

Hein M, Valore EV, Helmig RB, Uldbjerg N \& Ganz T 2002 Antimicrobial factors in the cervical mucus plug. American Journal of Obstetrics and Gynecology 187 137-144. (doi:10.1067/mob.2002.123034)

Heine RP, Wiesenfeld H, Mortimer L \& Greig PC 1998 Amniotic fluid defensins: potential markers of subclinical intrauterine infection. Clinical Infectious Diseases 27 513-518. (doi:10.1086/514691)

Helmig R, Uldbjerg N \& Ohlsson K 1995 Secretory leukocyte protease inhibitor in the cervical-mucus and in the fetal membranes. European Journal of Obstetrics, Gynecology, and Reproductive Biology 59 95-101. (doi:10.1016/0028-2243(94)02023-8)

Helmig BR, Romero R, Espinoza J, Chaiworapongsa T, Bujold E, Gomez R, Ohlsson K \& Uldbjerg N 2002 Neutrophil elastase and secretory leukocyte protease inhibitor in prelabor rupture of membranes, parturition and intra-amniotic infection. Journal of Maternal-Fetal \& Neonatal Medicine 12 237-246. (doi:10.1080/jmf.12.4.237.246)

Hollox EJ, Davies J, Griesenbach U, Burgess J, Alton EWFW \& Armour JAL 2005 Beta-defensin genomic copy number is not a modifier locus for cystic fibrosis. Journal of Negative Results in Biomedicine 4 9. (doi:10. 1186/1477-5751-4-9)

Horne AW, Stock SJ \& King AE 2008 Innate immunity and disorders of the female reproductive tract. Reproduction 135 739-749. (doi:10.1530/ REP-07-0564)

Jenssen H, Hamill P \& Hancock REW 2006 Peptide antimicrobial agents Clinical Microbiology Reviews 19 491-511. (doi:10.1128/CMR.0005605)

Jia HP, Schutte BC, Schudy A, Linzmeier R, Guthmiller JM, Johnson GK, Tack BF, Mitros JP, Rosenthal A, Ganz T et al. 2001 Discovery of new human beta-defensins using a genomics-based approach. Gene 263 211-218. (doi:10.1016/S0378-1119(00)00569-2)

Jin FY, Nathan C, Radzioch D \& Ding A 1997 Secretory leukocyte protease inhibitor: a macrophage product induced by and antagonistic to bacterial lipopolysaccharide. Cell 88 417-426. (doi:10.1016/S00928674(00)81880-2)

Jones HE, Harris KA, Azizia M, Bank L, Carpenter B, Hartley JC, Klein N \& Peebles D 2009 Differing prevalence and diversity of bacterial species in fetal membranes from very preterm and term labor. PLoS ONE 4 e8205. (doi:10.1371/journal.pone.0008205)

Kaushic C 2011 HIV-1 infection in the female reproductive tract: role of interactions between HIV-1 and genital epithelial cells. American Journal of Reproductive Immunology 65 253-260. (doi:10.1111/ j.1600-0897.2010.00965.x)
Kikuchi T, Abe T, Satoh K, Narumi K, Sakai T, Abe S, Shindoh S, Matsushima K \& Nukiwa T 1997 Cis-acting region associated with lung cell-specific expression of the secretory leukoprotease inhibitor gene. American Journal of Respiratory Cell and Molecular Biology 17 361-367.

King AE, Critchley HOD \& Kelly RW 2000 Presence of secretory leukocyte protease inhibitor in human endometrium and first trimester decidua suggests an antibacterial protective role. Molecular Human Reproduction 6 191-196. (doi:10.1093/molehr/6.2.191)

King AE, Critchley HOD, Sallenave JM \& Kelly RW 2003a Elafin in human endometrium: an antiprotease and antimicrobial molecule expressed during menstruation. Journal of Clinical Endocrinology and Metabolism 88 4426-4431. (doi:10.1210/jc.2003-030239)

King AE, Fleming DC, Critchley HOD \& Kelly RW 2003b Differential expression of the natural antimicrobials, beta-defensins 3 and 4 , in human endometrium. Journal of Reproductive Immunology 59 1-16. (doi:10.1016/S0165-0378(02)00083-9)

King AE, Kelly RW, Sallenave JM, Bocking AD \& Challis JRG 2007a Innate immune defences in the human uterus during pregnancy. Placenta $\mathbf{2 8}$ 1099-1106. (doi:10.1016/j.placenta.2007.06.002)

King AE, Paltoo A, Kelly RW, Sallenave JM, Bocking AD \& Challis JRG $2007 b$ Expression of natural antimicrobials by human placenta and fetal membranes. Placenta 28 161-169. (doi:10.1016/j.placenta.2006.01. 006)

Klotman ME \& Chang TL 2006 Defensins in innate antiviral immunity. Nature Reviews. Immunology 6 447-456. (doi:10.1038/nri1860)

Lai YP \& Gallo RL 2009 AMPed up immunity: how antimicrobial peptides have multiple roles in immune defense. Trends in Immunology $\mathbf{3 0}$ 131-141. (doi:10.1016/j.it.2008.12.003)

Lehrer RI 2004 Primate defensins. Nature Reviews. Microbiology 2 727-738. (doi:10.1038/nrmicro976)

Mandic Havelka A, Yektaei-Karin E, Hultenby K, Sørensen OE, Lundahl J, Berggren V \& Marchini G 2010 Maternal plasma level of antimicrobial peptide LL37 is a major determinant factor of neonatal plasma LL37 level. Acta Paediatrica 99 836-841. (doi:10.1111/j.1651-2227.2010. 01726.x)

Marchini G, Lindow S, Brismar H, Stabi B, Berggren V, Ulfgren AK, LonneRahm S, Agerberth B \& Gudmundsson GH 2002 The newborn infant is protected by an innate antimicrobial barrier: peptide antibiotics are present in the skin and vernix caseosa. British Journal of Dermatology 147 1127-1134. (doi:10.1046/j.1365-2133.2002.05014.x)

Maruyama M, Hay JG, Yoshimura K, Chu CS \& Crystal RG 1994 Modulation of secretory leukoprotease inhibitor gene-expression in human bronchial epithelial-cells by phorbol eater. Journal of Clinical Investigation 94 368-375. (doi:10.1172/JCI117331)

Matsuzaki K 1999 Why and how are peptide-lipid interactions utilized for self-defense? Magainins and tachyplesins as archetypes. Biochimica et Biophysica Acta 1462 1-10. (doi:10.1016/S0005-2736(99)00197-2)

McMichael JW, Roghanian A, Jiang L, Ramage R \& Sallenave JM 2005 The antimicrobial antiproteinase elafin binds to lipopolysaccharide and modulates macrophage responses. American Journal of Respiratory Cell and Molecular Biology 32 443-452. (doi:10.1165/rcmb.2004-0250OC)

Murakami M, Lopez-Garcia B, Braff M, Dorschner RA \& Gallo RL 2004 Postsecretory processing generates multiple cathelicidins for enhanced topical antimicrobial defense. Journal of Immunology 172 3070-3077.

Nara K, Ito S, Ito T, Suzuki Y, Ghoneim MA, Tachibana S \& Hirose S 1994 Elastase inhibitor elafin is a new-type of proteinase-inhibitor which has a transglutaminase-mediated anchoring sequence termed cementoin. Journal of Biochemistry 115 441-448.

Oppenheim JJ, Biragyn A, Kwak LW \& Yang D 2003 Roles of antimicrobial peptides such as defensins in innate and adaptive immunity. Annals of the Rheumatic Diseases 62 17-21. (doi:10.1136/ard.62.suppl_2.ii17)

Pfundt $R$, vanRuissen F, vanVlijmenWillems I, Alkemade HAC, Zeeuwen $P$, Jap PH, Dijkman H, Fransen J, Croes H, vanErp PEJ et al. 1996 Constitutive and inducible expression of SKALP/elafin provides antielastase defense in human epithelia. Journal of Clinical Investigation 98 1389-1399. (doi:10.1172/JCI118926)

Pfundt R, Wingens $M$, Bergers $M$, Zweers $M$, Frenken $M$ \& Schalkwijk J 2000 TNF-alpha and serum induce SKALP/elafin gene expression in human keratinocytes by a p38 MAP kinase-dependent pathway. Archives of Dermatological Research 292 180-187. (doi:10.1007/ s004030050475) 
Reddy KVR, Yedery RD \& Aranha C 2004 Antimicrobial peptides: premises and promises. International Journal of Antimicrobial Agents 24 536-547. (doi:10.1016/j.ijantimicag.2004.09.005)

Rice WG, Ganz T, Kinkade JM, Selsted ME, Lehrer RI \& Parmley RT 1987 Defensin-rich dense granules of human-neutrophils. Blood 70 757-765.

Romero R, Chaiworapongsa T \& Espinoza J 2003 Micronutrients and intrauterine infection, preterm birth and the fetal inflammatory response syndrome. Journal of Nutrition 133 1668S-11673.

Romero R, Espinoza J, Gonçalves LsF, Kusanovic JP, Friel LA \& Nien JK 2006 Inflammation in preterm and term labour and delivery. Seminars in Fetal \& Neonatal Medicine 11 317-326. (doi:10.1016/j.siny.2006.05. 001)

Romero R, Friel LA, Velez Edwards DR, Kusanovic JP, Hassan SS, Mazaki-Tovi S, Vaisbuch E, Kim CJ, Erez O, Chaiworapongsa T et al. 2010 A genetic association study of maternal and fetal candidate genes that predispose to preterm prelabor rupture of membranes (PROM). American Journal of Obstetrics and Gynecology 203 361e361-361e330. (doi:10.1016/j.ajog.2010.05.026)

Rosenfeld Y, Papo N \& Shai Y 2006 Endotoxin (lipopolysaccharide) neutralization by innate immunity host-defense peptides - peptide properties and plausible modes of action. Journal of Biological Chemistry 281 1636-1643. (doi:10.1074/jbc.M504327200)

Sallenave J-M 2010 Secretory leukocyte protease inhibitor and elafin/ trappin-2: versatile mucosal antimicrobials and regulators of immunity. American Journal of Respiratory, Cell and Molecular Biology 42 635-643. (doi:10.1165/rcmb.2010-0095RT)

Sallenave JM \& Silva A 1993 Characterization and gene sequence of the precursor of Elafin, an elastase-specific inhibitor in bronchial-secretions. American Journal of Respiratory Cell and Molecular Biology 8 439-445.

Sallenave JM, Shulmann J, Crossley J, Jordana M \& Gauldie J 1994 Regulation of secretory leukocyte proteinase-inhibitor (SIpi) and elastasespecific inhibitor (Esi/Elafin) in human airway epithelial-cells by cytokines and neutrophilic enzymes. American Journal of Respiratory Cell and Molecular Biology 11 733-741.

Sallenave JM, Si-Tahar M, Cox G, Chignard M \& Gauldie J 1997 Secretory leukocyte proteinase inhibitor is a major leukocyte elastase inhibitor in human neutrophils. Journal of Leukocyte Biology 61 695-702.

Schalkwijk J, Wiedow O \& Hirose S 1999 The trappin gene family: proteins defined by an $\mathrm{N}$-terminal transglutaminase substrate domain and a C-terminal four-disulphide core. Biochemical Journal 340 569-577. (doi:10.1042/0264-6021:3400569)

Schaller-Bals S, Schulze A \& Bals R 2002 Increased levels of antimicrobial peptides in tracheal aspirates of newborn infants during infection. American Journal of Respiratory and Critical Care Medicine 165 992-995.

Scheetz T, Bartlett JA, Walters JD, Schutte BC, Casavant TL \& McCray PB 2002 Genomics-based approaches to gene discovery in innate immunity. Immunological Reviews 190 137-145. (doi:10.1034/j.1600-065X.2002. 19010.x)

Schutte BC, Mitros JP, Bartlettt JA, Walters JD, Jia HP, Welsh MJ, Casavant TL \& McCray PB 2002 Discovery of five conserved betadefensin gene clusters using a computational search strategy. PNAS 99 2129-2133. (doi:10.1073/pnas.042692699)

Seemuller U, Arnhold M, Fritz H, Wiedenmann K, Machleidt W, Heinzel R, Appelhans H, Gassen HG \& Lottspeich F 1986 The acid-stable proteinase-inhibitor of human mucous secretions (Husi-I, antileukoprotease) - complete amino-acid-sequence as revealed by protein and Cdna sequencing and structural homology to whey proteins and red-sea turtle proteinase-inhibitor. FEBS Letters 199 43-48. (doi:10.1016/00145793(86)81220-0)

Selsted ME, Miller SI, Henschen AH \& Ouellette AJ 1992 Enteric defensins - antibiotic peptide components of intestinal host defense. Journal of Cell Biology 118 929-936. (doi:10.1083/jcb.118.4.929)

Shai Y 1999 Mechanism of the binding, insertion and destabilization of phospholipid bilayer membranes by alpha-helical antimicrobial and cell non-selective membrane-lytic peptides. Biochimica et Biophysica Acta 1462 55-70. (doi:10.1016/S0005-2736(99)00200-X)

Simcox R, Sin W-TA, Seed PT, Briley A \& Shennan AH 2007 Prophylactic antibiotics for the prevention of preterm birth in women at risk: a meta-analysis. Australian and New Zealand Journal of Obstetrics and Gynaecology 47 368-377. (doi:10.1111/j.1479-828X.2007.00759.x)
Simpson AJ, Cunningham GA, Porteous DJ, Haslett C \& Sallenave JM 2001 Regulation of adenovirus-mediated elafin transgene expression by bacterial lipopolysaccharide. Human Gene Therapy 12 1395-1406. (doi:10.1089/104303401750298553)

Soboll G, Schaefer TM \& Wira CR 2006 Effect of Toll-like receptor (TLR) agonists on TLR and microbicide expression in uterine and vaginal tissues of the mouse. American Journal of Reproductive Immunology $\mathbf{5 5}$ 434-446. (doi:10.1111/j.1600-0897.2006.00381.x)

Sorensen OE 2005 The human cathelicidin hCAP-18. Danish Medical Bulletin 52 1-10.

Soto E, Espinoza J, Nien JK, Kusanovic JP, Erez O, Richani K, SantolayaForgas J \& Romero R 2007 Human beta-defensin-2: a natural antimicrobial peptide present in amniotic fluid participates in the host response to microbial invasion of the amniotic cavity. Journal of Maternal-Fetal \& Neonatal Medicine 20 15-22. (doi:10.1080/ 14767050601036212)

Starner TD, Agerberth B, Gudmundsson GH \& McCray PB 2005 Expression and activity of beta-defensins and LL-37 in the developing human lung. Journal of Immunology 174 1608-1615.

Stock SJ, Kelly RW, Riley SC \& Calder AA 2007 Natural antimicrobial production by the amnion. American Journal of Obstetrics and Gynecology 196 255e251-255e256. (doi:10.1016/j.ajog.2006.10.908)

Stock SJ, Duthie L, Tremaine T, Calder AA, Kelly RW \& Riley SC 2009 Elafin (SKALP/Trappin-2/proteinase inhibitor-3) is produced by the cervix in pregnancy and cervicovaginal levels are diminished in bacterial vaginosis. Reproductive Sciences 16 1125-1134. (doi:10.1177/ 1933719109341998)

Svinarich DM, Gomez R \& Romero R 1997a Detection of human defensins in the placenta. American Journal of Reproductive Immunology $\mathbf{3 8}$ 252-255.

Svinarich DM, Wolf NA, Gomez R, Gonik B \& Romero R $1997 b$ Detection of human defensin 5 in reproductive tissues. American Journal of Obstetrics and Gynecology 176 470-475. (doi:10.1016/S00029378(97)70517-9)

Tang YQ, Yuan J, Osapay G, Osapay K, Tran D, Miller CJ, Ouellette AJ \& Selsted ME 1999 A cyclic antimicrobial peptide produced in primate leukocytes by the ligation of two truncated alpha-defensins. Science $\mathbf{2 8 6}$ 498-502. (doi:10.1126/science.286.5439.498)

Tejera P, Wang Z, Zhai R, Su L, Sheu C-C, Taylor DM, Chen F, Gong MN, Thompson BT \& Christiani DC 2009 Genetic polymorphisms of peptidase inhibitor 3 (Elafin) are associated with acute respiratory distress syndrome. American Journal of Respiratory Cell and Molecular Biology 41 696-704. (doi:10.1165/rcmb.2008-04100C)

Thompson RC \& Ohlsson K 1986 Isolation, properties, and complete amino-acid-sequence of human secretory leukocyte protease inhibitor, a potent inhibitor of leukocyte elastase. PNAS 83 6692-6696. (doi:10. 1073/pnas.83.18.6692)

Tollin M, Bergsson G, Kai-Larsen $Y$, Lengqvist J, Sjovall J, Griffiths W, Skuladottir GV, Haraldsson A, Jornvall H, Gudmundsson GH et al. 2005 Vernix caseosa as a multi-component defence system based on polypeptides, lipids and their interactions. Cellular and Molecular Life Sciences 62 2390-2399. (doi:10.1007/s00018-005-5260-7)

Tremblay GM, Vachon E, Larouche C \& Bourbonnais Y 2002 Inhibition of human neutrophil elastase-induced acute lung injury in hamsters by recombinant human pre-elafin (trappin-2). Chest 121 582-588. (doi:10. 1378/chest.121.2.582)

Tromp G, Kuivaniemi H, Romero R, Chaiworapongsa T, Kim YM, Kim MR, Maymon E \& Edwin S 2004 Genome-wide expression profiling of fetal membranes reveals a deficient expression of proteinase inhibitor 3 in premature rupture of membranes. American Journal of Obstetrics and Gynecology 191 1331-1338. (doi:10.1016/j.ajog.2004.07.010)

Tsutsumi-Ishii Y \& Nagaoka I 2002 NF-kappa B-mediated transcriptional regulation of human beta-defensin-2 gene following lipopolysaccharide stimulation. Journal of Leukocyte Biology 71 154-162.

Valore EV, Park CH, Quayle AJ, Wiles KR, McCray PB \& Ganz T 1998 Human beta-defensin-1: an antimicrobial peptide of urogenital tissues. Journal of Clinical Investigation 101 1633-1642. (doi:10.1172/ JCI1861)

Valore EV, Park CH, Igreti SL \& Ganz T 2002 Antimicrobial components of vaginal fluid. American Journal of Obstetrics and Gynecology 187 561-568. (doi:10.1067/mob.2002.125280) 
Valore EV, Wiley DJ \& Ganz T 2006 Reversible deficiency of antimicrobial polypeptides in bacterial vaginosis. Infection and Immunity $\mathbf{7 4}$ 5693-5702. (doi:10.1128/IAI.00524-06)

Venkataraman N, Cole AL, Ruchala P, Waring AJ, Lehrer RI, Stuchlik O, Pohl J \& Cole AM 2009 Reawakening retrocyclins: ancestral human defensins active against HIV-1. PLoS Biology 7 e1000095. (doi:10.1371/ journal.pbio.1000095)

Westin U, Polling A, Ljungkrantz I \& Ohlsson K 1999 Identification of SLP (secretory leukocyte protease inhibitor) in human mast cells using immunohistochemistry and in situ hybridisation. Biological Chemistry 380 489-493. (doi:10.1515/BC.1999.063)

Wilkinson TS, Dhaliwal K, Hamilton TW, Lipka AF, Farrell L, Davidson DJ, Duffin R, Morris AC, Haslett C, Govan JRW, Gregory CD, Sallenave JM \& Simpson AJ 2009 Trappin-2 promotes early clearance of pseudomonas aeruginosa through CD14-dependent macrophage activation and neutrophil recruitment. American Journal of Pathology 174 1338-1346. (doi:10. 2353/ajpath.2009.080746)

Williams SE, Brown TI, Roghanian A \& Sallenave J-M 2006 SLPI and elafin: one glove, many fingers. Clinical Science 110 21-35. (doi:10.1042/ CS20050115

Wingens M, van Bergen BH, Hiemstra PS, Meis J, van Vlijmen-Willems I, Zeeuwen P, Mulder J, Kramps HA, van Ruissen F \& Schalkwijk J 1998 Induction of SLPI (ALP/HUSI-I) in epidermal keratinocytes. Journal of Investigative Dermatology 111 996-1002. (doi:10.1046/j.1523-1747. 1998.00425.x)

Xu J, Holzman CB, Arvidson CG, Chung H \& Goepfert AR 2008 Midpregnancy vaginal fluid defensins, bacterial vaginosis, and risk of preterm delivery. Obstetrics and Gynecology 112 524-531. (doi:10. 1097/AOG.0b013e318184209b)

Yamaguchi Y, Nagase T, Makita R, Fukuhara S, Tomita T, Tominaga T, Kurihara H \& Ouchi Y 2002 Identification of multiple novel epididymisspecific beta-defensin isoforms in humans and mice. Journal of Immunology $1692516-2523$.
Yang L, Weiss TM, Lehrer RI \& Huang HW 2000 Crystallization of antimicrobial pores in membranes: magainin and protegrin. Biophysical Journal 79 2002-2009. (doi:10.1016/S0006-3495(00)76448-4)

Yoshio $\mathbf{H}$, Tollin $\mathbf{M}$, Gudmundsson $\mathbf{G H}$, Lagercrantz $\mathbf{H}$, Jornvall $\mathbf{H}$, Marchini G \& Agerberth B 2003 Antimicrobial polypeptides of human vernix caseosa and amniotic fluid: implications for newborn innate defense. Pediatric Research 53 211-216. (doi:10.1203/01.PDR. 0000047471.47777.B0)

Zasloff M 2002 Antimicrobial peptides in health and disease. New England Journal of Medicine 347 1199-1200. (doi:10.1056/NEJMe020106)

Zhang M, Zou ZQ, Maass N \& Sager R 1995 Differential expression of Elafin in human normal mammary epithelial-cells and carcinomas is regulated at the transcriptional level. Cancer Research 55 2537-2541.

Zhang Q, Shimoya K, Moriyama A, Yamanaka K, Nakajima A, Nobunaga T, Koyama M, Azuma C \& Murata Y 2001 Production of secretory leukocyte protease inhibitor by human amniotic membranes and regulation of its concentration in amniotic fluid. Molecular Human Reproduction 7 573-579. (doi:10.1093/molehr/7.6.573)

Zimmermann GR, Legault P, Selsted ME \& Pardi A 1995 Solution structure of bovine neutrophil beta-defensin-12 - the peptide fold of the betadefensins is identical to that of the classical defensins. Biochemistry $\mathbf{3 4}$ 13663-13671. (doi:10.1021/bi00041a048)

Received 23 December 2010

First decision 21 February 2011

Revised manuscript received 21 March 2011

Accepted 7 April 2011 